\title{
Assessment of Technological Gap and Productivity Gain in Cowpea through Front Line Demonstrations
}

\author{
Shaukat Ali ${ }^{1}$, Balbir Singh, Aditi Gupta and Ajesh Kumar \\ Krishi Vigyan Kendra, Chandgothi, Churu-331305 (Rajasthan), India \\ *Corresponding author
}

\section{A B S T R A C T}

Keywords

Cowpea, Grain yield, Economics,

Technology gap,

Extension gap

\section{Article Info}

Accepted:

23 April 2020

Available Online:

10 May 2020
KVK, Chandgothi, Churu (Rajasthan) conducted total 50 Front Line Demonstrations on cowpea at farmers field in Churu District (Rajasthan) during two consecutive kharif seasons from 2014 to 2015. The farming situation was rainfed and soil was sandy loam low in nitrogen, medium in phosphorus and medium to high in potash. Assessment of gap was done and on the basis of gap assessment, improved recommended technologies were demonstrated. On overall average basis, $19.98 \%$ higher grain yield was recorded under demonstrations than the farmer's traditional practices (Local check). The extension gap, technology gap and technology index were $195 \mathrm{~kg} / \mathrm{ha},-170 \mathrm{~kg} / \mathrm{ha}$ and 16.64 per cent, respectively. An additional investments of Rs 300 per ha consist with scientific monitoring of demonstration and non-monetary factors resulted in additional return of Rs. 6393 per ha. On two year average basis incremental benefit : cost ratio was found 21.31 .

\section{Introduction}

Pulses are the backbone of Indian agriculture as well as pulses play important role in Indian cropping systems. Pulse crops are primarily grown under rainfed condition and a low fertility neglected soil in India. It can be grown on a variety of soil and climatic conditions as it is tolerant to drought (Malik et al., 2006). Pulse or 'Daal' are an integral part of the average Indian meal. A large population of the Indian population is vegetarian and pulses form the main source of protein. The protein content in pulses is about 18-25 per cent. This makes pulses one of the cheapest sources of protein for human consumption (Dayanand et al., 2014). Pulse is the second most important groups after cereals (Dash and Rautaray, 2017). The per capita availability of pulses has declined from $60.55 \mathrm{~g} /$ day in 1951 to $41.64 \mathrm{~g} /$ day in 2012. The productivity of pulses is very low in India is $588 \mathrm{~kg} / \mathrm{ha}$, as compared to highest 2034 $\mathrm{kg} / \mathrm{ha}$ in USA during 2016 (Anonymous, 
2018). In Rajasthan state, the total area under cowpea cultivation is 93,619 hectares with production of 38,152 MT. The average productivity of cowpea in Rajasthan is 408 $\mathrm{kg} / \mathrm{ha}$. So far, as Churu district of Rajasthan is concerned total area under cowpea cultivation 4,685 hectare with productivity of $633 \mathrm{~kg} / \mathrm{ha}$ (Anonymous 2017-18), which is much lower than the potential.

At present the productivity of cowpea is not sufficient due to several biotic and abiotic stresses besides unavailability of quality seeds of improved varieties in time and poor crop management practices due to unawareness and non adoption of recommended production and plant protection technologies. To enhance the productivity of cowpea, it is necessary to cultivate cowpea in scientific manner and brought the newly developed production technologies at farmer's field. Therefore, Front Line Demonstration on cowpea at farmer's field may be helpful to establish the technology at farming community. The basic objective of this programme is to demonstrate improve proven technologies of recently released, short duration, high yielding disease resistant varieties in compact block with INM, IWM and IPM at farmer's field (Table 1) through Krishi Vigyan Kendras to enhanced adoption of modern technologies to generate yield data with farmers feedback. Keeping this in view, KVK, Chandgothi, Churu conducted 50 demonstrations on cowpea crop at farmer's field during kharif 2014 to kharif 2015. The objectives of this study were as follows:

To find out the performance of recognized and recommended high yielding variety of cowpea with full recommended package of practices.

To compare the yield of FLD organized by $\mathrm{KVK}$ with local check (farmer's practices).

To collect and consider the feedback information from farmers for further improvement in research.

\section{Materials and Methods}

KVK, Chandgothi, Churu conducted total 50 Front Line Demonstrations on cowpea variety RC 19 at 50 selected farmer's field in a compact block in Churu District (Rajasthan) during kharif 2014 and kharif 2015. The selection of villages was done on basis of non adoption of improved and recommended variety (RC 19). After the selection of villages, most approachable side of farmer's field was selected, so that the performance of demonstrated technology can be seen by other farmers. The farming situation was rainfed and soil was sandy loam low in nitrogen, medium in phosphorus and medium to high in potash. The area for demonstration was 0.4 ha each and were conducted by using recommended package of practices. The KVK provided high quality seed of cowpea variety i.e. RC $19 @ 15 \mathrm{~kg} / \mathrm{ha}$ and other critical input like DAP, micro-nutrients, bio fertilizers, herbicide and pesticides were purchased by the farmers and used with the guidance of KVK during both the years. The sowing of crops was done on the onset of monsoon, most of time it was mid July and harvested during first week of October. The scientist of KVK, Chandgothi, Churu regularly visited and monitored demonstrations on farmers fields from sowing to harvesting. The grain yield of demonstration and local check was recorded and analyzed. Other parameters as suggested by Verma et al., (2014) were used for calculating gap analysis, cost and returns. The details of different parameters are as follows:

Extension gap $=$ Demonstration yield $\left(D_{1}\right)$ Farmers practices yield $\left(\mathrm{F}_{1}\right)$

Technology gap $=$ Potential yield $\left(\mathrm{P}_{1}\right)$ Demonstration yield $\left(\mathrm{D}_{1}\right)$ 
Technology index $=$

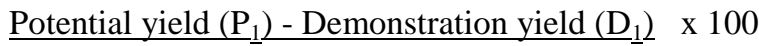
Potential yield $\left(\mathrm{P}_{1}\right)$

Additional return $=$ Demonstration return $\left(D_{r}\right)$ - Farmers practices return $\left(F_{r}\right)$

Effective gain = Additional return $\left(\mathrm{A}_{\mathrm{r}}\right)$ Additional cost $\left(\mathrm{D}_{\mathrm{c}}\right)$

Incremental $\mathbf{B}: \mathbf{C}$ ratio $=\underline{\text { Additional return }\left(\mathrm{A}_{\mathrm{r}}\right)}$ Additional cost $\left(\mathrm{D}_{\mathrm{c}}\right)$

\section{Results and Discussion}

\section{Grain yield}

The average grain yield of cowpea under demonstration plot was recorded $1170 \mathrm{~kg} / \mathrm{ha}$, while, in farmer's practices plot it was 975 $\mathrm{kg} / \mathrm{ha}$ (Table 3 \& Fig. 2). The grain yield was increased from 18.51 to 21.45 per cent over farmer's practices (local check) during both the years. On average basis, 19.98 per cent increase in yield was recorded under demonstrations plot as compared to farmer's local cultivation practices of cowpea. While it was $110.43,350.00$ and 17.00 per cent higher as compared to state, district yield and potential yield (Table $2 \&$ Fig. 1).

\section{Gap analysis}

An extension gap between demonstrated technology and farmer's practices was ranged from $185 \mathrm{~kg} / \mathrm{ha}$ to $204 \mathrm{~kg} / \mathrm{ha}$ during both the year. On two year average basis, extension gap of total 50 demonstrations was observed $195 \mathrm{~kg} / \mathrm{ha}$ (Table 3). Such big gap might be attributed to adoption of improved technology in demonstration which resulted in higher grain yield than the traditional farmer's practices. Wide technology gap of -184 to $155 \mathrm{~kg} / \mathrm{ha}$ in yield was observed during the demonstrations years. Average technology gap of 50 demonstrations was $-170 \mathrm{~kg} / \mathrm{ha}$.
Minus data in technology gap during both the years indicated more feasibility of recommended technologies during study periods. Lower technology gap showed (Table 3) that combination of improved varieties with recommended package of practices perform better than the potential yield of varieties. Similarly, the technology index for all the demonstrations during the study period were in accordance with technology gap. Technology index were ranged from 15.63 per cent to 17.66 per cent with an average of 16.64 per cent. Lower technology index reflected the adequate proven technology for transferring to farmers and sufficient extension services for transfer of technology.

\section{Economics analysis}

Improved variety seed, fertilizers, bio fertilizers, herbicides and pesticides were considered as cash inputs for the demonstrations as well as farmers practices. On an average additional investment of Rs 300 per hectare was made under demonstration resulted in additional return of Rs 6,393 per hectare. Economics returns as a function of grain yield and selling price varied during both the years. The total return under demonstration plot was ranged from Rs 29,600 per hectare to Rs 46,200 per hectare with an average of Rs 37,900 per hectare. Higher return was obtained during year 2015 due to higher grain yield and higher selling price. While, in farmer's local practices plot total return ranged from 24,975 Rs per hectare to $38,040 \mathrm{Rs}$ per hectare with an average of 31,508 Rs per hectare (Table 4). The higher effective gain of 6,093 Rs per hectare was obtained under demonstration. The higher additional returns and effective gain under demonstration could be due to improved technology, non-monetary factors, timely operations of crop cultivation and scientific monitoring. The Incremental $\mathrm{B}: \mathrm{C}$ ratio 
(IBCR) during both the years was found between 15.42 to 27.20. On the average of two years, IBCR was found 21.31. Higher IBCR could be due to higher additional return with low additional cost in demonstration.

The results confirm with the finding of Front Line Demonstration on oilseeds, pulse and clusterbean crops by Dayanand et al., (2014), Dwivedi et al., (2018), Rachhoya et al., (2018), Rawat and Rajput (2018), Singh and Sharma (2018), Jain et al., (2019), Ali and Singh (2020) and Bamboriya et al., (2020).

Table.1 Comparison between technological intervention and local check and gap analysis under FLDs on cowpea

\begin{tabular}{|c|c|c|c|c|}
\hline $\begin{array}{l}\text { Sr. } \\
\text { No. }\end{array}$ & Particulars & $\begin{array}{l}\text { Technological Intervention } \\
\text { (Demonstration Practices ) }\end{array}$ & $\begin{array}{l}\text { Farmers Practices } \\
\text { (Local Check) }\end{array}$ & $\begin{array}{l}\text { Technological } \\
\text { Gap }\end{array}$ \\
\hline 1. & $\begin{array}{l}\text { Farming } \\
\text { Situation }\end{array}$ & Rainfed & Rainfed & No Gap \\
\hline 2. & Variety & Improved variety i.e. RC 19 & Locally available & $\begin{array}{l}\text { Full Gap }(100 \\
\%)\end{array}$ \\
\hline 3. & Seed Rate & $15 \mathrm{~kg} / \mathrm{ha}$ & $15 \mathrm{~kg} / \mathrm{ha}$ & No Gap \\
\hline 4. & $\begin{array}{l}\text { Seed } \\
\text { inoculation }\end{array}$ & Rhizobium and PSB & No Seed Inoculation & $\begin{array}{l}\text { Full Gap }(100 \\
\%)\end{array}$ \\
\hline 5. & Sowing Method & Line Sowing $(30 \times 10 \mathrm{~cm})$ & $\begin{array}{l}\text { Line Sowing }(30 \times 10 \\
\mathrm{cm})\end{array}$ & No Gap \\
\hline 6. & Fertilizer & $15 \mathrm{~kg} \mathrm{~N}, 40 \mathrm{~kg} \mathrm{P}_{2} \mathrm{O}_{5}$ & No use of fertilizer & $\begin{array}{l}\text { Full Gap (100 } \\
\%)\end{array}$ \\
\hline 7. & Micro-nutrients & $\begin{array}{c}\text { Use of micro nutrients for } \\
\text { balance fertilizer ( } 75 \mathrm{gm} / 15 \\
\text { liters of water as foliar } \\
\text { spray) }\end{array}$ & $\begin{array}{c}\text { No use of } \\
\text { Micronutrients }\end{array}$ & $\begin{array}{l}\text { Full Gap }(100 \\
\%)\end{array}$ \\
\hline 8. & Weed Control & $\begin{array}{c}\text { Herbicide application } \\
\text { (Imazethapyr @ } 500 \mathrm{ml} / \mathrm{ha} \\
\text { at } 15-20 \mathrm{DAS})\end{array}$ & $\begin{array}{l}\text { Hand weeding at } 25 \\
\text { DAS }\end{array}$ & $\begin{array}{c}\text { No herbicide use } \\
\text { Full Gap (100 } \\
\%)\end{array}$ \\
\hline 9. & Plant protection & $\begin{array}{c}\text { Need based spray of } \\
\text { Insecticides and fungicides }\end{array}$ & No spray & $\begin{array}{l}\text { Full Gap }(100 \\
\%)\end{array}$ \\
\hline
\end{tabular}

Table.2 Comparison of yields of cowpea (Average of 2014 \& 2015)

\begin{tabular}{|c|c|c|c|c|c|}
\hline & State* & District* & Potential & $\begin{array}{c}\text { Demonstratio } \\
\text { n }\end{array}$ & $\begin{array}{c}\text { Farmers } \\
\text { practices }\end{array}$ \\
\hline $\begin{array}{c}\text { Yield } \\
\text { (kg/ha) }\end{array}$ & 556 & 260 & 1000 & 1170 & 975 \\
\hline$\%$ increased & 110.43 & 350.00 & 17.00 & -- & 19.98 \\
\hline
\end{tabular}

*Anonymous (2015-16) 
Table.3 Grain yield and gap analysis and technology index of Front Line Demonstration on cowpea at farmer's field

\begin{tabular}{|c|c|c|c|c|c|c|c|c|c|}
\hline $\begin{array}{c}\text { Year of } \\
\text { demonstration }\end{array}$ & No. of Demo & Variety & $\begin{array}{c}\text { Potential } \\
\text { Yield } \\
\text { (kg/ha) }\end{array}$ & $\begin{array}{c}\text { Demo yield } \\
\text { (Kg/ha) }\end{array}$ & $\begin{array}{c}\text { Farmers } \\
\text { practices } \\
\text { yield (kg/ha) }\end{array}$ & $\begin{array}{c}\text { Increased } \\
\text { over Farmers } \\
\text { practices }(\%)\end{array}$ & $\begin{array}{c}\text { Extension } \\
\text { gap } \\
\text { (kg/ha) }\end{array}$ & $\begin{array}{c}\text { Technology } \\
\text { gap } \\
\text { (kg/ha) }\end{array}$ & $\begin{array}{c}\text { Technology } \\
\text { index } \\
(\%)\end{array}$ \\
\hline Kharif, 2014 & 25 & RC 19 & 1000 & 1184 & 999 & 18.51 & 185 & -184 & 15.63 \\
\hline Kharif, 2015 & 25 & RC 19 & 1000 & 1155 & 951 & 21.45 & 204 & -155 & 17.66 \\
\hline Average & -- & -- & 1000 & 1170 & 975 & 19.98 & 195 & -170 & 16.64 \\
\hline
\end{tabular}

Table.4 Economics analysis of Front Line Demonstration on cowpea at farmer's field

\begin{tabular}{|c|c|c|c|c|c|c|c|c|c|}
\hline \multirow{2}{*}{$\begin{array}{c}\text { Year of } \\
\text { demonstration }\end{array}$} & \multicolumn{2}{|c|}{ Cost of Cultivation (Rs/ha) } & \multirow{2}{*}{$\begin{array}{l}\text { Additional cost } \\
\text { in demo } \\
(\mathrm{Rs} / \mathrm{ha})\end{array}$} & \multirow{2}{*}{$\begin{array}{l}\text { Sale Price } \\
\text { of grain } \\
\text { (Rs/qt.) }\end{array}$} & \multicolumn{2}{|c|}{ Total return (Rs/ha) } & \multirow{2}{*}{$\begin{array}{c}\text { Additional } \\
\text { return in demo } \\
\text { (Rs/ha) }\end{array}$} & \multirow{2}{*}{$\begin{array}{l}\text { Effective } \\
\text { gain } \\
\text { (Rs/ha) }\end{array}$} & \multirow{2}{*}{$\begin{array}{c}\text { Incremental } \\
\text { B:C ratio } \\
\text { (IBCR) }\end{array}$} \\
\hline & Demo & $\begin{array}{l}\text { Farmers } \\
\text { practices }\end{array}$ & & & Demo & $\begin{array}{l}\text { Farmers } \\
\text { practices }\end{array}$ & & & \\
\hline Kharif, 2014 & 10200 & 9900 & 300 & 2500 & 29600 & 24975 & 4625 & 4325 & 15.42 \\
\hline Kharif, 2015 & 12200 & 11900 & 300 & 4000 & 46200 & 38040 & 8160 & 7860 & 27.20 \\
\hline Average & 11200 & 10900 & 300 & 3250 & 37900 & 31508 & 6393 & 6093 & 21.31 \\
\hline
\end{tabular}

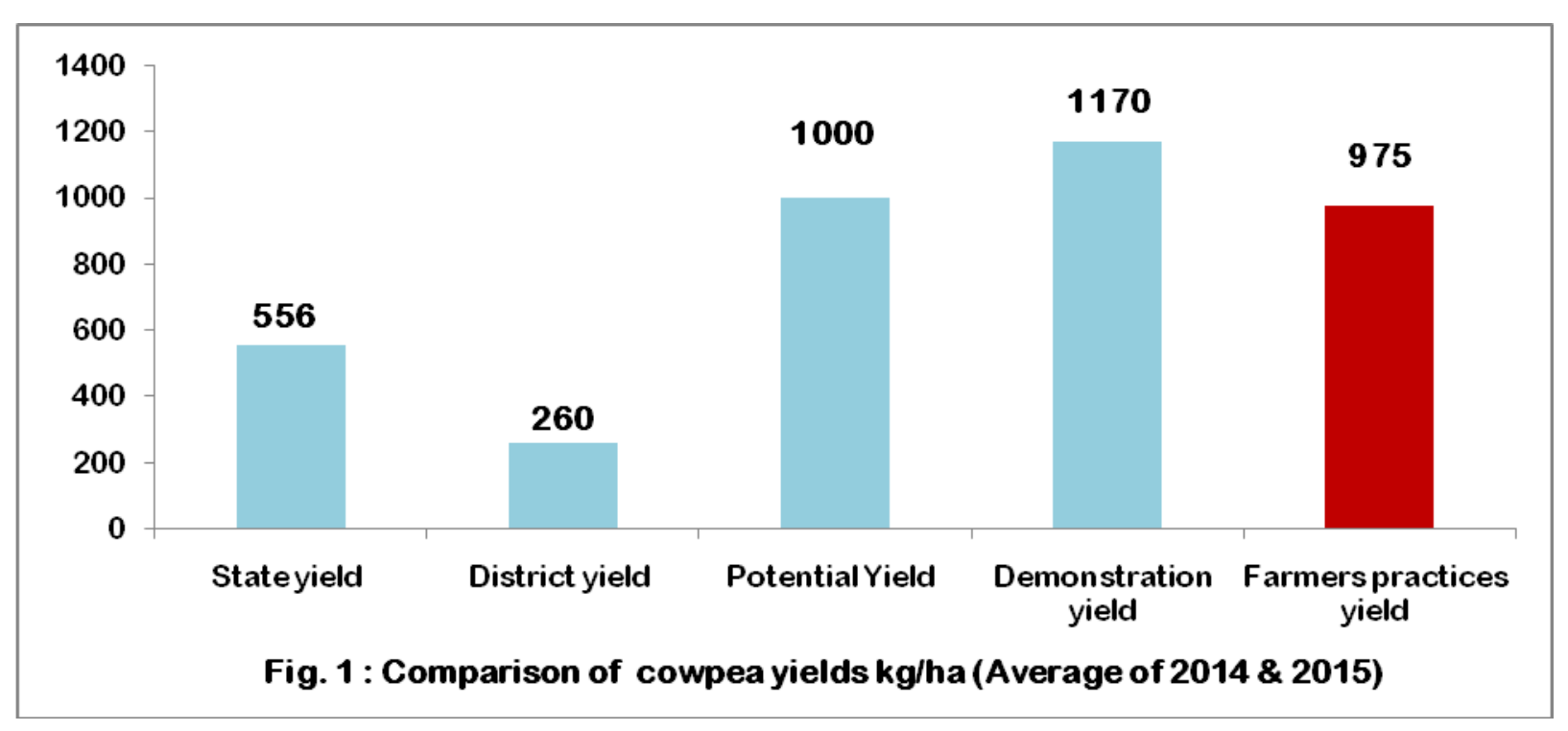




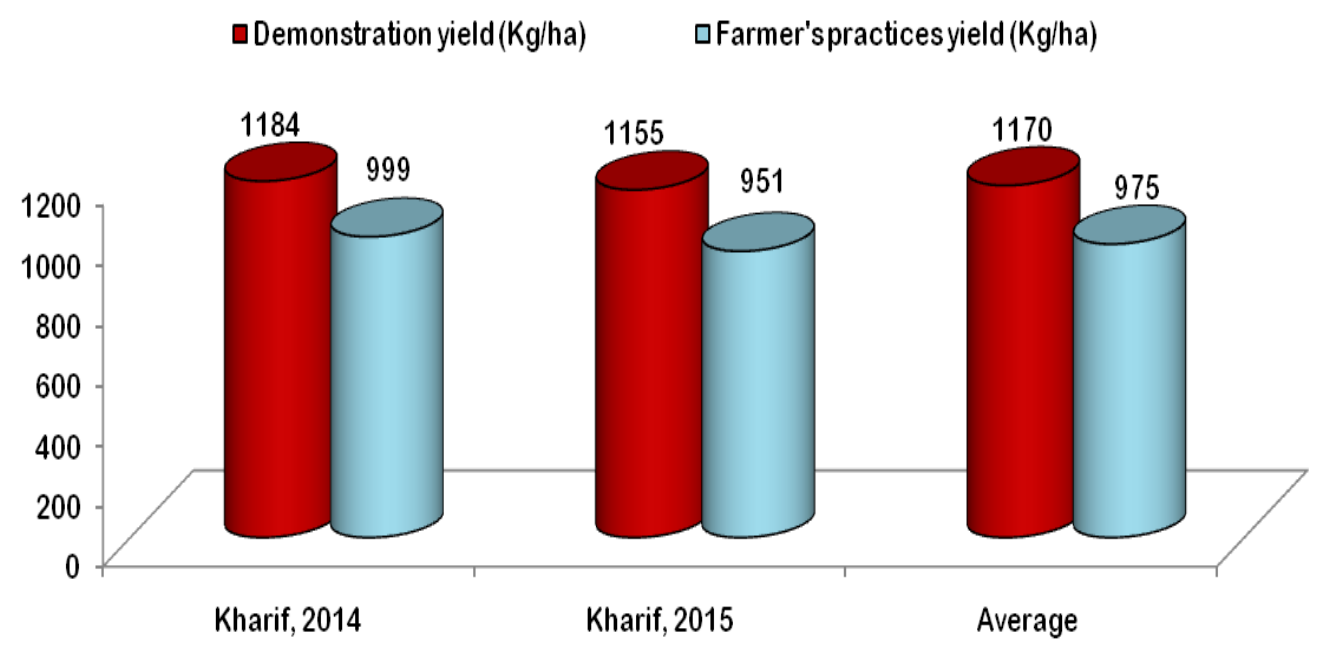

Fig. 2: Grain yield of Cowpea in demonstration and farmer's practices plot

On the basis of two years of Front Line Demonstration it can be concluded that by adopting recommended package of practices under demonstration can increased 19.98 per cent yield of cowpea over farmer's practices. The increase was recorded with little extra spending of Rs 300 per hectare. This amount is not big enough that even a small and marginal farmer can afford this. The adoption of improved technology not affected by the additional cost but the ignorance and unawareness is the primary reason and it is quite appropriate to call such yield gap as extension gap. Moreover, extension gap can be also be minimized by adopting such technology under FLD. The IBCR (21.31) is much high to motivate the farmers for adoption of technology. Therefore, Front Line Demonstration of cowpea was found effective for farmers in changing mind sate, attitude, skill and knowledge of improved practices of cowpea cultivation including adaption. Farmers and scientist relationship also improved by this and built confidence between them. Demonstrated farmers is a good primary source of knowledge or information on improved practices of cowpea cultivation and also source of good quality seed in locality and surrounding area for next season. Front Line Demonstration helps in speedy and wider dissemination of the improved proven technology to the farming community.

\section{References}

Ali, S. and Singh, B. (2020). Impact of front line demonstration on productivity and profitability of rainfed cluster bean in Churu district of Rajasthan. Forage Res., 45(4): 335-338.

Anonymous (2015-16). Rajasthan Agricultural Statistics at Glance, Commissionerate of Agriculture, Jaipur, Rajasthan.

Anonymous (2017-18). Rajasthan Agricultural Statistics at Glance, Commissionerate of Agriculture, Jaipur, Rajasthan.

Anonymous (2018). Agriculture Statistics at a Glance. Directorate of Economics \& Statistics, Department of Agriculture \& Cooperation, New Delhi.

Bamboriya, S.D., Singh, G., Jat, A.S. and 
Singh, I. (2020). Evaluation of front line demonstration trials on clusterbean in Nagaur district of Rajasthan, India. Int. J. Curr. Microbiol. App. Sci., 9(1): 1909-1913.

Dash, S. R. and Rautaray, B. K. (2017). Growth Parameters and Yield of Green Gram Varieties (Vigna radiata L.) in East and South East Coastal Plain of Odisha, India. Int. J. Curr. Microbiol. App. Sci., 6(10): 1517-1523.

Dayanand; Verma, R. K. and Mehta, S. M. (2014). Assessment of technology gap and productivity gain through front line demonstration in chickpea. Legume Research, 37(4): 430-433.

Dwivedi1, R. K., Tiwari, B. K. and Baghel, K. S. (2018). Role of cluster frontline demonstration in enhancement of blackgram production. Plant Archives, 18(1): 1088-1090.

Jain, L.K., Parewa, H.R. and Ratnoo, S.D. (2019). Impact of frontline demonstration on productivity and profitability analysis of cluster bean in Barmer district of Rajasthan. Forage Res., 44(4): 282-285.
Malik, A., Fayyaz-Ul- Hassan, A., Abdul Wahieed, A., Qadir, G. and Asghar, R. (2006). In reactive effects of irrigation and Phosphorus on green gram Vigna radiata L, Pakisthan J. Bot., 38(4): 1119- 1126.

Rachhoya, H. K., Sharma, M. and Sodh, K. R. (2018). Evaluation of yield performance of Mustard (Brassica juncea) through Cluster Front Line Demonstration. Int. J. Curr. Microbiol. App. Sci., 7 (7).

Rawat, G. S. and Rajput, R. L. (2018). Profitability of clusterbean through front line demonstrations. Bhartiya Krishi Anushandhan Patrika, 33 (1): 48-50.

Singh, B. and Sharma, A.K. (2018). Impact of front line demonstrations on productivity enhancement of cluster bean in arid zone. Indian J. of Ext. Edu., 54(1): 130-133

Verma, R. K; Dayanand, Rathore, R. S., Mehta, S.M. and Singh, M. (2014). Yield and gap analysis of wheat productivity through frontline demonstrations in Jhunjhunu district of Rajasthan. Ann. Agric. Res., 35: 79-82.

\section{How to cite this article:}

Shaukat Ali, Balbir Singh, Aditi Gupta and Ajesh Kumar. 2020. Assessment of Technological Gap and Productivity Gain in Cowpea through Front Line Demonstrations. Int.J.Curr.Microbiol.App.Sci. 9(05): 2771-2777. doi: https://doi.org/10.20546/ijcmas.2020.905.319 